\title{
The Influences of $\mathrm{G}$ Proteins, $\mathrm{Ca}^{2+}$, and $\mathrm{K}^{+}$Channels on Electrical Field Stimulation in Cat Esophageal Smooth Muscle
}

\author{
Jun Hong Park ${ }^{1, *}$, Hyun Sik Kim ${ }^{1, *}$, Sun Young Park ${ }^{1}$, Chaeuk Im ${ }^{1}$, Ji Hoon Jeong ${ }^{2}$, In Kyeom Kim ${ }^{3}$, \\ and Uy Dong Sohn ${ }^{1}$ \\ ${ }^{1}$ College of Pharmacy and ${ }^{2}$ School of Medicine, Chung-Ang University, Seoul 156-756, and ${ }^{3}$ School of Medicine, Kyungpook National \\ University, Daegu 700-422, Korea
}

\begin{abstract}
NO released by myenteric neurons controls the off contraction induced by electrical field stimulation (EFS) in distal esophageal smooth muscle, but in the presence of nitric oxide synthase (NOS) inhibitor, L-NAME, contraction by EFS occurs at the same time. The authors investigated the intracellular signaling pathways related with $G$ protein and ionic channel EFS-induced contraction using cat esophageal muscles. EFS-induced contractions were significantly suppressed by tetrodotoxin (1 $\mu$ M) and atropine $(1 \mu \mathrm{M})$. Furthermore, nimodipine inhibited both on and off contractions by EFS in a concentration dependent meaner. The characteristics of 'on' and 'off contraction and the effects of G-proteins, phospholipase, and $\mathrm{K}^{+}$channel on EFS-induced contraction in smooth muscle were also investigated. Pertussis toxin (PTX, a $\mathrm{G}_{\mathrm{i}}$ inactivator) attenuated both EFS-induced contractions. Cholera toxin (CTX, $\mathrm{G}_{\mathrm{s}}$ inactivator) also decreased the amplitudes of EFS-induced off and on contractions. However, phospholipase inhibitors did not affect these contractions. Pinacidil (a $\mathrm{K}^{+}$channel opener) decreased these contractions, and tetraethylammonium (TEA, $\mathrm{K}^{+}{ }_{\mathrm{Ca}}$ channel blocker) increased them. These results suggest that EFS-induced on and off contractions can be mediated by the activations $\mathrm{Gi}$ or Gs proteins, and that L-type $\mathrm{Ca}^{2+}$ channel may be activated by G-protein $\alpha$ subunits. Furthermore, $\mathrm{K}^{+} \mathrm{Ca}^{-}$channel involve in the depolarization of esophageal smooth muscle. Further studies are required to characterize the physiological regulation of $\mathrm{Ca}^{2+}$ channel and to investigate the effects of other $\mathrm{K}^{+}$channels on EFS-induced on and off contractions.
\end{abstract}

Key Words: EFS, Cat esophageal, Circular smooth muscle, NO, L-type $\mathrm{Ca}^{2+}$ channel

\section{INTRODUCTION}

At rest, the esophagus is relaxed but opens readily to accept food and liquids. The upper portion of esophagus is composed of muscle similar to those of the arms and legs (skeletal muscle), and is therefore under voluntary control. The other two thirds of the esophagus are composed of smooth muscle and are under involuntary control. These smooth muscles form an inner circular and an outer longitudinal layer (Pope, 1997).

Peristalsis in the skeletal muscle segment of the esophagus results from central neural sequencing, whereas central and peripheral neural mechanisms are primarily responsible for peristalsis in the smooth muscle segment (Roman, 1966; Roman and Car, 1967). Esophageal peristalsis is dependent on the integration of inhibitory and excitatory neuronal mechanisms, and if a short train stimulus is applied to circular smooth muscle strips in vitro it evokes

Received September 15, 2009, Revised September 24, 2009,

Accepted October 12, 2009

Corresponding to: Uy Dong Sohn, Department of Pharmacology, College of Pharmacy, Chung-Ang University, 221, Heukseok-dong, Dongjak-gu, Seoul 156-756, Korea. (Tel) 82-2-820-5614, (Fax) 82-2-826-8752, (E-mail) udsohn@cau.ac.kr

*The first two authors contributed equally to this article. a contraction after a certain latency from stimulus discontinuation (Weisbrodt and Christensen, 1972). Accordingly, this contraction is called the 'off response', which coincides with the depolarization of circular muscle following electrical field stimulation (EFS)-induced muscle hyperpolarization (Crist et al., 1984).

Atropine potently blocks off contraction, which indicates the prominent role of muscarinic cholinergic excitation and contraction of esophageal smooth muscle (Diamant, 1989). Furthermore, esophageal contraction in response to Ach is mediated by $\mathrm{M}_{2}$ muscarinic receptors, since Ach-induced contraction is selectively inhibited by the $\mathrm{M}_{2}$ muscarinic antagonist methoctramine, and $\mathrm{M}_{2}$ muscarinic receptors are linked mostly to $\mathrm{G}_{\mathrm{i} 3}$, because the Ach-induced contraction of permeable cells is inhibited by antibodies against the $\alpha$-subunit of $\mathrm{G}_{\mathrm{i} 3}$ (Sohn et al., 1993; Sohn et al., 1995). G-proteins are linked to phospholipase, and these interactions generate intracellular second messengers from membrane phospholipids. In addition, Ach-induced contraction of esophageal circular muscle cells is inhibited by selective inhibitors and by antibodies of phosphatidylcholine-specific phospholipase C (PC-PLC), PLD, and $\mathrm{CPLA}_{2}$,

ABBREVIATIONS: EFS, electrical field stimulation; NOS, nitric oxide synthase; NO, nitric oxide; PC-PLC, phosphatidylcholinespecific phospholipase C; TEA, tetraethylammonium; CTX, cholera toxin; PTX, pertussis toxin. 
which suggests a linkage exists between $\mathrm{G}_{\mathrm{i} 3}$ and these phospholipases (Sohn et al., 1993; Sohn et al., 1995). The Achinduced contraction and activation of phospholipase requires the influx of extracellular $\mathrm{Ca}^{2+}$ (Sohn et al., 1994), and the muscarinic excitation of the human esophagus involves the release of $\mathrm{Ca}^{2+}$ from intracellular stores and $\mathrm{Ca}^{2+}$ influx (Sims et al., 1997).

Nitric oxide (NO) (Murray et al., 1991; Tottrup et al., 1991; Yamato et al., 1992) and vasoactive intestinal polypeptide (Goyal et al., 1980; Biancani et al., 1984; Behar et al., 1989; Rattan and Chakder, 1992) have been proposed as neurotransmitters that control LES relaxation and/or esophageal peristalsis. NO activates $\mathrm{K}^{+}$channel via the guanosine 3',5'-cyclic monophosphate-protein kinase $\mathrm{G}$ signal transduction pathway (Dalziel et al., 1991; Archer et al., 1994; Bolotina et al., 1994; Miyoshi and Nakaya, 1994; Murray et al., 1995), which suggests that $\mathrm{K}^{+}$channel opening is associated with the hyperpolarization induced by $\mathrm{NO}$ in esophageal muscle, and the presence of the NOS (nitric oxide synthase) inhibitor, L-NAME, decreased off contraction in a concentration-dependent manner, but on contraction latency was unaffected.

It has been established that ligand-gated ion channels are activated in three ways: a) by the ligand-gated opening of an ion channel by a messenger substance, b) by direct coupling between an ion channel and a G-protein, or c) by control of the open state by intracellular messengers (Jessell and Kandel, 1993; Kelly, 1993; Unwin, 1993). Ach-induced $\mathrm{Ca}^{2+}$ channel opening plays an important role in the contraction of esophageal smooth muscle, but it is not known what mechanisms are involved in the activation of $\mathrm{Ca}^{2+}$ channel during nerve-mediate smooth muscle contraction.

In this in vitro study, we examined the effects of G-proteins and phospholipases, which are required for $\mathrm{Ca}^{2+}$ channel activation, on 'on' and 'off' contractions. In addition, we also studied the involvement of $\mathrm{K}^{+}$channel on both contraction types in cat esophageal circular muscle.

\section{METHODS}

\section{Animals}

Adult cats of either sex weighing between 2.5 and $5 \mathrm{~kg}$ were used in this study. Cats were anesthetized with ketamine $(50 \mathrm{mg} / \mathrm{ml} / \mathrm{kg}$ ) and sacrificed by bleeding. Chests and abdomen were opened with a mid-line incision to expose the esophagus and stomach, which were then removed together and pinned on wax blocks in their in vivo orientations. In each case, the esophagus and stomach were opened along the lesser curvature, and the location of the squamo-columnar junction was identified and the mucosa peeled. The high-pressure zone is characterized by a visible thickening of the circular muscle layer at the squamocolumnar junction and immediately proximal to the sling fibers of the stomach. We previously showed that a $5 \sim 8 \mathrm{~mm}$ band of tissue, which coincides with the thickened region, constitutes the LES. Esophageal body segments extending from 1 to $3 \mathrm{~cm}$ above the LES were selected for experiments. This constituted the distal most portion of the esophagus and comprised $\sim 15 \%$ of its length.

\section{Tissue bath studies}

Transversely oriented muscle strips $(2 \mathrm{~mm}$ wide and 7 mm long) were taken from esophageal body segments. These were then cut into $4 \sim 5$ strips, and silk-ligatures were tied to strip ends. These muscle strips were then mounted individually in $1 \mathrm{ml}$ muscle chambers. One ligature was fixed and the other was attached to a force transducer (FT03 Grass Instruments Co., Quincy, Mass., USA). Changes in isometric force were recorded on a polygraph (Grass model 79).

The muscle strips were initially placed under a tension of $2 \mathrm{~g}$ for optimal force development, and were equilibrated for $2 \mathrm{hr}$ while being perfused continuously with oxygenated Krebs. During this time, the tensions in the muscle strips decreased rapidly and stabilized at less than $0.5 \mathrm{~g}$. The solution used was equilibrated with a gas mixture containing $95 \% \mathrm{O}_{2}$ and $5 \% \mathrm{CO}_{2}$ at $\mathrm{pH} 7.4$ and $37^{\circ} \mathrm{C}$.

\section{Electrical field stimulation experiments}

The strips were stimulated with pulse trains of amplitude $80 \mathrm{~V}$ and duration 10 seconds, at a pulse duration of 1 milliseconds and a frequency of $4 \mathrm{~Hz}$ using a stimulator (model S 88; Grass Instruments) delivered through platinum wire electrodes placed longitudinally on opposite sides of strips. After a stable resting muscle strip tone had been obtained, the frequency-response relationship $(4 \mathrm{~Hz})$ was constructed and the rings were washed three times and allowed to equilibrate for $30 \mathrm{~min}$ after EFS to permit complete strip recovery from contractile responses to EFS.

\section{'On' and 'off' contraction}

'Off' contractions by EFS occurred after a latency period from stimulus termination in the absence of an NOS inhibitor, whereas 'on' contraction by EFS occurred after a latency period from stimulus initiation in the presence of an NOS inhibitor.

\section{Muscle strip treatments}

Control responses to EFS of resting circular smooth muscle tension were investigated. To confirm that response to EFS were neuronal in origin, some preparations were pretreated with tetrodotoxin $(1 \mu \mathrm{M})$ for $15 \mathrm{~min}$, and to determine whether cholinergic neurotransmission was involved in response to EFS, strips were pretreated with atropine $(1 \mu \mathrm{M})$ for 15 min. In addition, to confirm that $\mathrm{Ca}^{2+}$ influx play a critical role in contraction, strips were pretreated with nimodipine (an L-type $\mathrm{Ca}^{2+}$ channel blocker) for 5 min at concentrations of $10^{-10}$ to $10^{-6}$. To assess the effects of $\mathrm{G}_{\mathrm{S}}$ and $\mathrm{G}_{\mathrm{i} / \mathrm{o}}$ proteins on circular smooth muscle contraction, PTX $(800 \mathrm{ng} / \mathrm{ml}), \mathrm{G}_{\mathrm{i}}$ inactivator, or CTX $(2 \mu \mathrm{g} / \mathrm{ml})$ (a GS inactivator) were pretreated for $2 \mathrm{hr}$, and measured on 'on' and 'off' contraction. In addition, to determine whether phospholipases were involved in response to EFS, strips were pretreated with D609 (a phosphatidylcholine-phospholipase C inhibitor; $10 \mu \mathrm{M}$ ), U73122 (a phosphatidylinositol-phospholipase C inhibitor; $10 \mu \mathrm{M}$ ), pCMB (a phospholipase D inhibitor; $10 \mu \mathrm{M}$ ), or DEDA (a phospholipase $\mathrm{A}_{2}$ inhibitor; $10 \mu \mathrm{M}$ ) for $20 \mathrm{~min}$. To investigate the involvement of protein kinase $\mathrm{C}$ in response to EFS, frequencyresponse curves were constructed in the presence of the protein kinase C inhibitor (GF109203X; $10 \mu \mathrm{M}$ ) for $20 \mathrm{~min}$. In addition, we examined whether $\mathrm{K}^{+}$channel was involved EFS induced contraction by pretreating muscle strips with pinacidil (a $\mathrm{K}^{+}$channel opener) for $5 \mathrm{~min}$ at concentrations 
of $10^{-7}$ to $10^{-4} \mathrm{M}$, and by pretreating strips with TEA chloride (a $\mathrm{Ca}^{2+}$ dependent $\mathrm{K}^{+}$channel blocker) for $5 \mathrm{~min}$ at concentrations of 0.1 to $2 \mathrm{mM}$.

\section{Solutions and drugs}

The esophaheal muscle strips were maintained in Krebs buffer of the following composition (Mm): $\mathrm{NaCl}$ 116.6, $\mathrm{NaHCO}_{3} 21.9, \mathrm{NaH}_{2} \mathrm{PO}_{4} 1.2, \mathrm{KCl} 3.4, \mathrm{CaCl}_{2} 2.5$, glucose 5.4, and $\mathrm{MgCl}_{2}$ 1.2. D609, U73122, DEDA, pCMB, TEA, and Nimodipine were purchased from Sigma (St. Louis, MO). Tetrodotoxin citrate and pinacidil were purchased from Tocris Cookson (Langford, UK). Atropine sulfate was purchased from Emerk (Darmstadt, Germany). Solutions were prepared immediately prior to experiments. Doses are provided as final molar concentrations in organ baths.

\section{Data analysis}

Amplitudes of contractions induced by EFS are expressed in grams (g), and data as means \pm SEMs. The Student's $t$-test for grouped data was used to determine statistical sig- nificances, which was accepted for $\mathrm{p}$ values of $<0.05$.

\section{RESULTS}

\section{Identifications of 'on' and 'off' contractions}

Muscle strips from esophageal smooth muscle contracted when stimulated by EFS. 'Off' contractions occurred after stimulus termination in the absence of an NOS inhibitor (Fig. 1A), whereas, 'on' contractions occurred after stimulus start in the presence of an NOS inhibitor, which was administered 10 before stimulation (Fig. 1B).

\section{Effect of atropine and tetrodotoxin on EFS-induced contractions}

'On' and 'off' contractions were abolished by tetrodotoxin $(1 \mu \mathrm{M})$, which suggested that both originated from nervemediated muscle excitation (Fig. 2A). Atropine $(1 \mu \mathrm{M})$ also blocked both contraction types (Fig. 2B), suggesting that cholinergic nerves were responsible for the contractions.
A

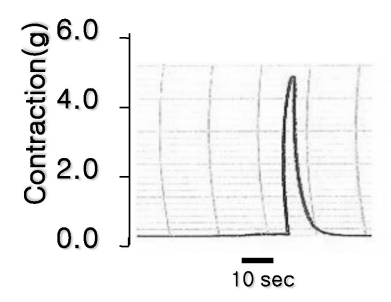

Off contraction

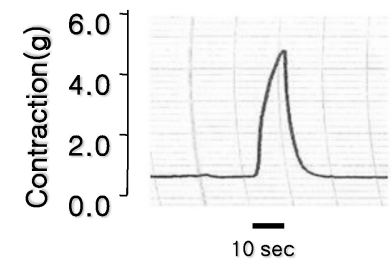

Pretreatment of L-NAME for $10 \mathrm{~min}$
On contraction

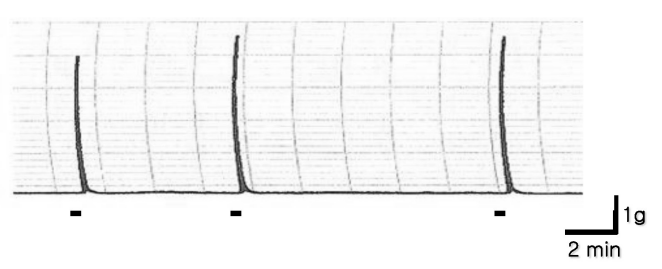

\section{Oncontraclion}

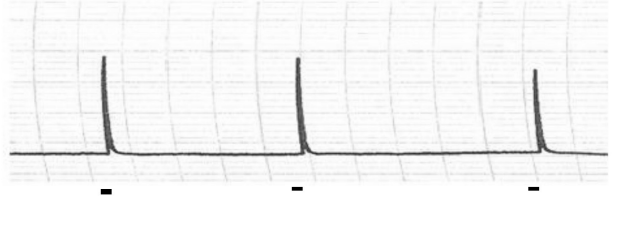

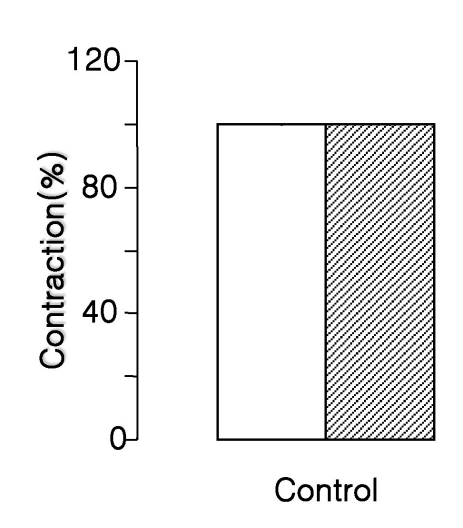
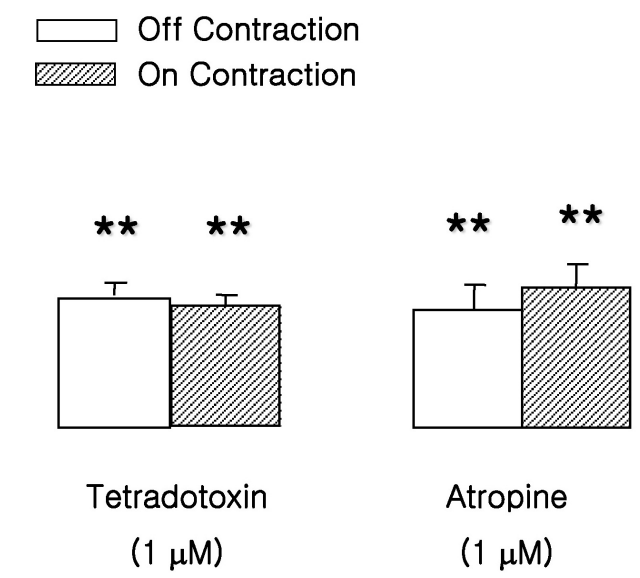

Atropine

$(1 \mu \mathrm{M})$
Fig. 1. Identification of 'on' and 'off' contraction. (A) 'Off' contractions were evoked by electrical field stimulation (EFS) in esophageal circular smooth muscle. (B) L-NAME $(100 \mu \mathrm{M}$, a NOS inhibitor) was pretreated for $10 \mathrm{~min}$, thus the contractions was provoked during EFS ('On' contractions).
Fig. 2. Effects of atropine and tetrodotoxin on EFS-induced contractions. 'On' and 'off' contractions were abolished by tetrodotoxin $(1 \mu \mathrm{M}$, administered $15 \mathrm{~min}$ before EFS) and atropine (1 $\mu \mathrm{M}, 15 \mathrm{~min}$ before EFS). Values are expressed as means \pm SEM. ${ }^{* *} \mathrm{p}<0.01$ versus control value. 


\section{L-type $\mathrm{Ca}^{2+}$ channel and EFS-induced contractions}

To determine whether L-type $\mathrm{Ca}^{2+}$ channel was involved the 'on' and 'off' contractions, muscle strips were exposed to nimodipine (a specific L-type $\mathrm{Ca}^{2+}$ channel inhibitor; $10^{-10}$ to $10^{-6} \mathrm{M}$ ) for $5 \mathrm{~min}$ before electrical stimulation. Nimodi-

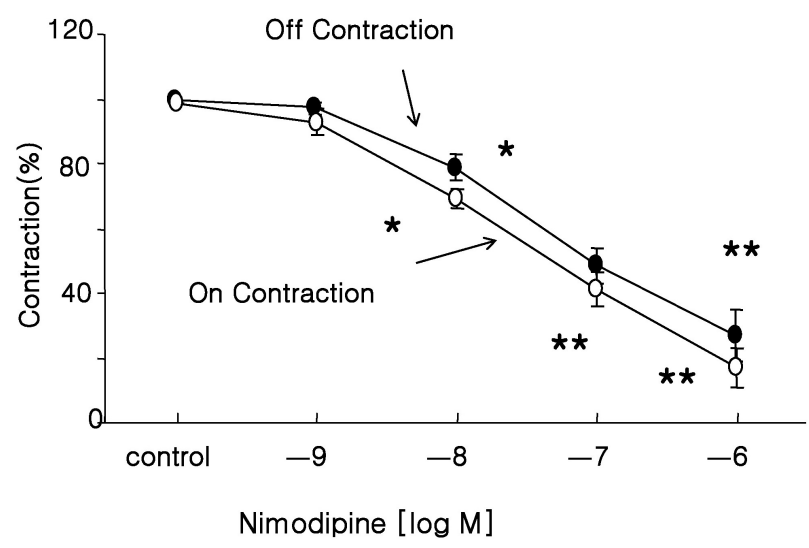

Fig. 3. Effect of $\mathrm{Ca}^{2+}$ blocker on EFS-induced contractions. Nimodipine (an L-type $\mathrm{Ca}^{2+}$ channel blocker) inhibited EFS-induced 'off' and 'on' contractions in a concentration-dependent manner, which suggested that $\mathrm{Ca}^{2+}$ channel contributes to the activation of muscle contraction in response to EFS. Values are expressed as means \pm SEM. ${ }^{*} \mathrm{p}<0.05,{ }^{* *} \mathrm{p}<0.01$ versus untreated controls. pine inhibited both EFS-induced contractions in a concentration-dependent manner. The amplitude of the 'off' contraction was decreased by $26 \%$ at $10^{-6} \mathrm{M}(\mathrm{n}=6, \mathrm{p}<0.01$, Fig. 3), and the amplitude of the 'on' contraction was similarly decreased by $21 \%$ at $10^{-6} \mathrm{M}(\mathrm{n}=6, \mathrm{p}<0.01)$.

\section{Effect of PTX and CTXs on EFS-induced contractions}

The strips were preincubated for $2 \mathrm{hr}$ with PTX at 800 $\mathrm{ng} / \mathrm{ml}$ ) before EFS. PTX was found to attenuate both contractions on response to EFS; the 'off' contraction was inhibited by $56 \%(\mathrm{n}=5, \mathrm{p}<0.01$, Fig. $4 \mathrm{~A})$, and the 'on' contraction was inhibited by $48 \%(n=5, p<0.01$, Fig. $4 A)$, suggesting that both contractions was mediated by the activation of PTX-sensitive Gi protein. Accordingly, strips were preincubated for $2 \mathrm{hr}$ with CTX (an Gs inhibitor at $2 \mu \mathrm{g} / \mathrm{ml}$ ) before EFS, and both contractions were decreased; the 'off' contraction was inhibited by $45 \%$ at $2 \mathrm{hr}(\mathrm{n}=5, \mathrm{p}<0.05$, Fig. $4 \mathrm{~B})$, and the 'on' contraction was inhibited by $46 \%(\mathrm{n}=5$, $\mathrm{p}<0.01$, Fig. 4B), suggesting that both contractions are mediated by Gs protein. From these results suggested that L-type $\mathrm{Ca}^{2+}$ channel opening involves $\mathrm{Gi}$ or Gs activation.

\section{Effect of phospholipase inhibitors on EFS-induced contractions}

To determine whether phospholipases (phospholipase C, phospholipase D, or phospholipase A2) are involved in EFSinduced muscle contraction, muscle strips were pretreated with $10 \mu \mathrm{M}$ of D609, DEDA, U73122, or pCMB for $20 \mathrm{~min}$ before EFS. However, none of these treatments signifi-

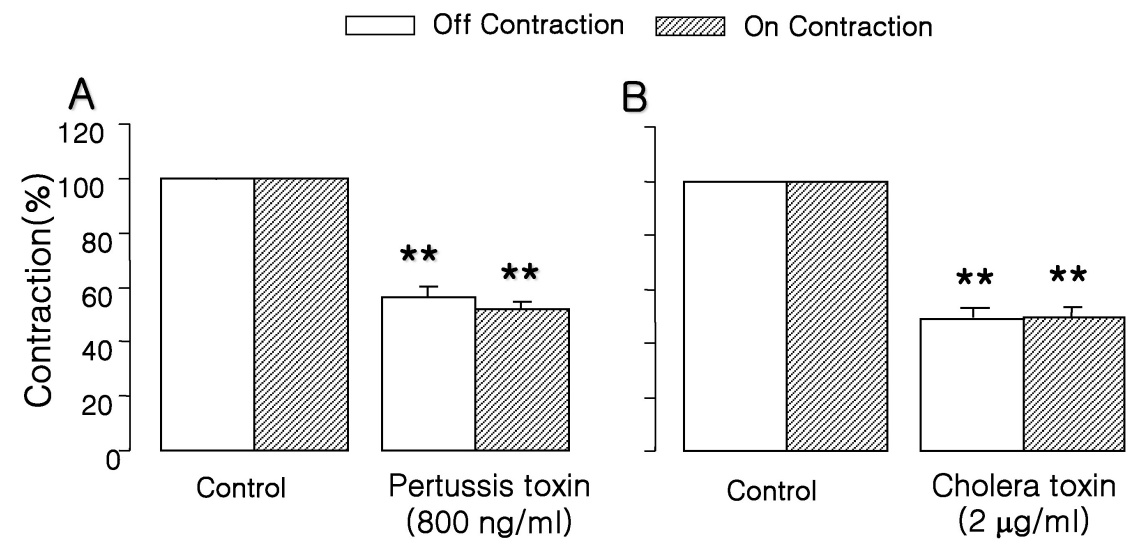

Fig. 4. Effects of PTX (A) and CTX (B) on response to EFS. EFS-induced contractions were significantly inhibited by PTX (800 $\mathrm{ng} / \mathrm{ml}$, a Gi inactivator, $\mathrm{n}=5$ ) after $2 \mathrm{hr}$ of pretreatment, which indicated that Gi protein mediated EFS-induced muscle contraction. Furthermore, EFS-induced contractions were also significantly inhibited by CTX $(2 \mu \mathrm{g} / \mathrm{ml}$, Gs inactivator, $n=5$ ), which indicated that Gs protein mediated EFS-induced muscle contraction. Values are expressed as means \pm SEM. ${ }^{* *} \mathrm{p}<0.01$ versus untreated controls.
A Off contraction

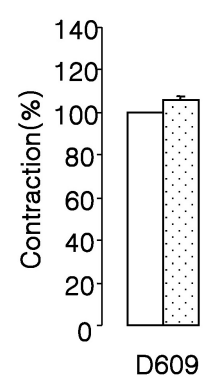

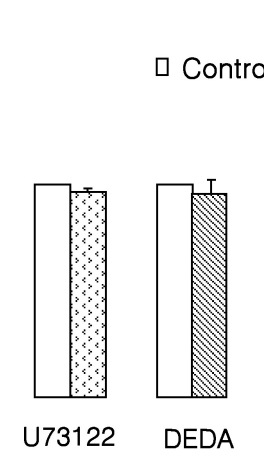

B

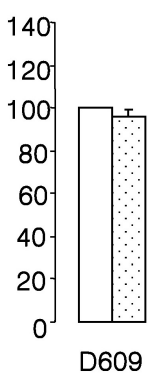

On contraction

\section{口 Control}

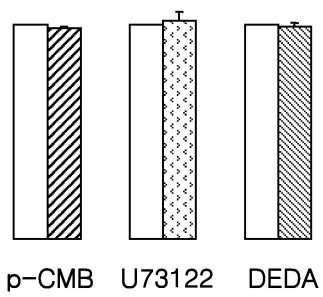

Fig. 5. Effects of phospholipases inhibitors on EFS-induced contractions. D609 $(10 \mu \mathrm{M}$, a phosphatidylcholine-PLC inhibitor), pCMB $(10 \mu \mathrm{M}$, a PLD inhibitor), U73122 $(10 \mu \mathrm{M}$, a phosphatidylinositol-PLC inhibitor), and DEDA $\left(10 \mu \mathrm{M}\right.$, a phospholipase $\left.\mathrm{A}_{2}\right)$ had no effect on EFS-induced (A) 'off' or (B) 'on' contractions. Values are expressed as means \pm SEMs. 


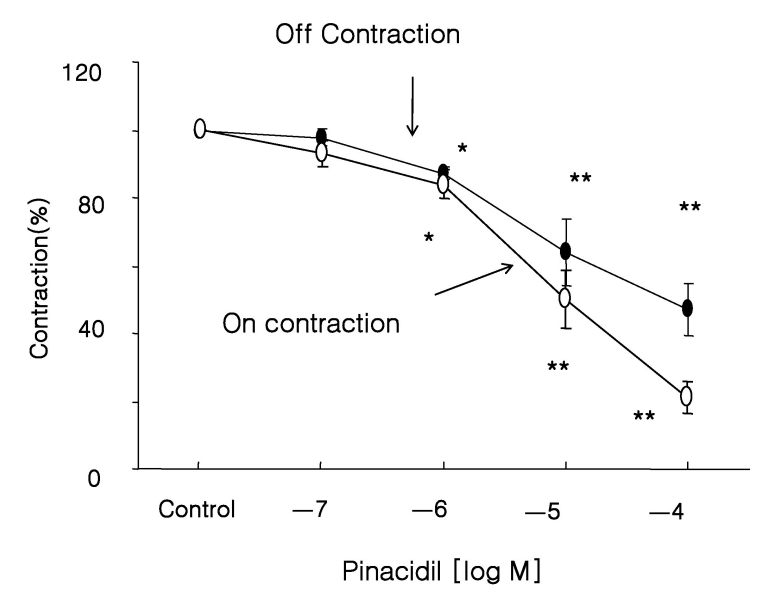

Fig. 6. Effect of a $\mathrm{K}^{+}$Channel opener on EFS-induced contractions. Pinacidil (a $\mathrm{K}^{+}$Channel opener) decreased the amplitude of both 'on' and 'off' EFS-induced contractions, which suggested that $\mathrm{K}^{+}$ efflux through $\mathrm{K}^{+}$channel reduced response to EFS. Values are expressed as means \pm SEMs. ${ }^{*} \mathrm{p}<0.05,{ }^{* *} \mathrm{p}<0.01$ versus untreated controls.

cantly affected EFS-induced 'on' or 'off' contractions (n=5 6, Fig. 5).

\section{Effect of $\mathrm{K}^{+}$channel on EFS-induced contractions}

To examine whether $\mathrm{K}^{+}$channel is involved in EFS-induced muscle contraction, muscle strips were pretreated with pinacidil (a $\mathrm{K}^{+}$channel opener, $10^{-7}$ to $10^{-4} \mathrm{M}$ ) or with TEA $\left(\mathrm{a} \mathrm{K}^{+}\right.$Ca channel blocker, 0.1, 0.5, 1, $2 \mathrm{mM}$ ) for 5 min before EFS. Pinacidil was found to decrease both EFS-induced contractions concentration dependently; the 'off' contraction was inhibited by $45 \%$ at $10^{-4} \mathrm{M}(\mathrm{n}=5$, Fig. $6, \mathrm{p}<0.01)$ and the 'on' contraction was inhibited by $24 \%$ at $10^{-4} \mathrm{M}(\mathrm{n}=5$, Fig. 6). On the other hand, TEA caused a concentration dependent contraction over the concentration range 0.1 to $2 \mathrm{mM}$; the 'off' contraction was increased by $173 \%$ by $2 \mathrm{mM}$ TEA ( $n=6$, Fig. 7, $\mathrm{p}<0.01$ ), and the 'on' contraction was increased by $210 \%$ at the same concentration.

\section{DISCUSSION}

Esophageal smooth muscle responds to stimulation with a period of inhibition during and shortly after stimulation by a contraction (Weisbrodt and Christensen, 1972). NO released from myenteric neurons controls both the amplitude and the timing of the 'off' contraction in smooth muscle in the distal esophagus (Murray et al., 1991). NO also mediates nerve-induced hyperpolarization of circular esophageal and LES smooth muscle (Christinck et al., 1991; Du et al., 1991). In the presence of the nitric oxide synthase (NOS) inhibitor, L-NAME, 'off' contraction is reduced concentration-dependently, but 'on' contraction is unaffected (Murray et al., 1991).

The activations of muscarinic receptors controls smooth muscle contraction in part by regulating the concentration of cytosolic free $\mathrm{Ca}^{2+}$ (van Breemen and Saida, 1989; Somlyo and Somlyo, 1994). Furthermore, atropine potently blocks peristalsis in the distal esophagus, which suggests that muscarinic cholinergic excitation play a in esophageal

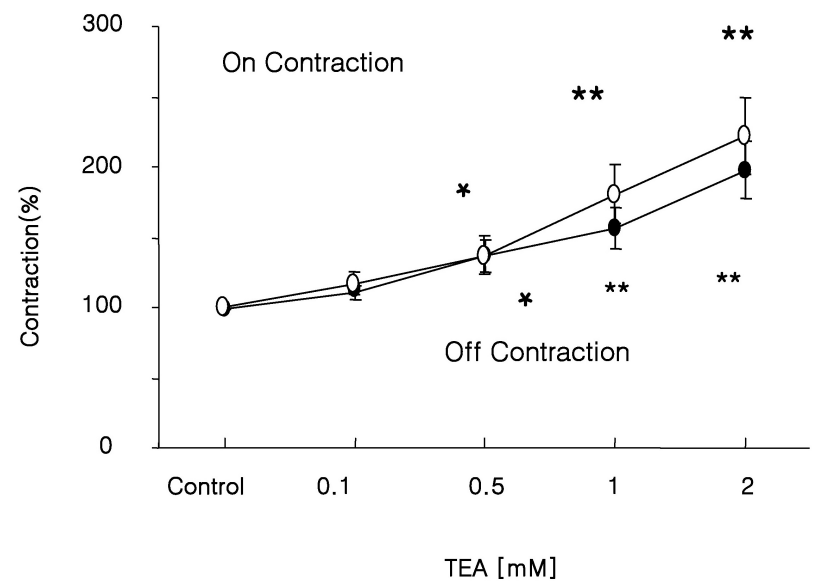

Fig. 7. Effect of $\mathrm{K}^{+}{ }_{\text {ca- }}$ Channel Blocker on response to EFS. EFS-induced 'off' and 'on' contractions were found to be augmented by TEA (a $\mathrm{Ca}^{2+}$-dependent $\mathrm{K}^{+}$channel blocker). Values are expressed as means \pm SEMs. ${ }^{*} \mathrm{p}<0.05,{ }^{* *} \mathrm{p}<0.01$ versus untreated controls.

smooth muscle contraction (Diamant, 1989). Moreover, $\left[\mathrm{Ca}^{2+}\right]_{\mathrm{i}}$ elevations can occur due to $\mathrm{Ca}^{2+}$ entry through ligand- or voltage- activated channels or by $\mathrm{Ca}^{2+}$ release from intracellular stores, the sarcoplasmic reticulum. The second messenger inositol 1,4,5-triphosphate $\left(\mathrm{IP}_{3}\right)$ is generated after the activations of some receptors and mediates the release of $\mathrm{Ca}^{2+}$ from stores in many cell types, including gastrointestinal smooth muscles (Berridge, 1993; Somlyo and Somlyo, 1994). A number of $\mathrm{Ca}^{2+}$ influx pathways have been described in smooth muscles. For example, agonist-mediated depolarization activates dihydropyridinesensitive $\mathrm{Ca}^{2+}$ channels (Sato et al., 1994), and can induce $\mathrm{Ca}^{2+}$ window currents or activate nonselective cationic channels (Fleischmann et al., 1994).

The studies of the cat esophageal body suggest that cholinergic excitation is mediated by the muscarinic $\mathrm{M}_{2}$ receptor subtype, with an absolute requirement for $\mathrm{Ca}^{2+}$ influx. In contrast, cholinergic excitation in the lower esophageal sphincter utilizes intracellular $\mathrm{Ca}^{2+}$ stores via a mechanism involving the $\mathrm{M}_{3}$-receptor subtype and the generation of $\mathrm{IP}_{3}$ (Biancani et al., 1987; Hillemeier et al., 1991; Sohn et al., 1993).

In the present study, we investigated muscarinic signaling in cat esophageal smooth muscle by studying intact muscle strip contraction. Other muscle contraction have confirmed the involvement of $\mathrm{Ca}^{2+}$ in EFS-induced 'on' and 'off' contractions, which is consistent with earlier observations in cat (Biancani et al., 1987; Hillemeier et al., 1991) and in man (Sims et al., 1997).

L-type $\mathrm{Ca}^{2+}$ channels are expressed by most of cell types, and regulate heartbeat, smooth muscle tonus, hormone secretion, and gene expression in the brain (Dascal, 2001), and are inhibited by neurotransmitters that act via PTXdependent $\mathrm{G}$ protein in many cell types. In smooth muscle cells, purified $\mathrm{G} \beta \gamma$ subunits infused during whole-cell recording enhance L-type via an indirect, phosphorylationrelated pathway (Viard et al., 1999; Zhong et al., 1999). The inhibition of L-type channels by opioid or ATP, mediated by PTX-sensitive G proteins in chromaffin cells, is membrane-delimited based on cell-attached-recording tests (Carabelli et al., 2001). G $\beta \gamma$ binds directly to the N- and 
C- termini of L-type channel, and the coexpression of G $\beta \gamma$ reduces $\mathrm{Ca}^{2+}$-channel currents in a $\mathrm{Ca}^{2+}$-calmodulin-dependent manner (Ivanina et al., 2000). In the present study, we examined whether G-proteins affect EFS-induced contractions, and whether phospholipases mediate muscle contractions in cat esophageal circular smooth muscle.

The several $\mathrm{G}$ proteins that have been characterized are all heterotrimeric, and their subunits have been designed $\alpha, \beta$, and $\gamma$ (Casey and Gilman, 1988). The $\alpha$ subunit contains a single, high-affinity binding site for guanine nucleotides and possesses GTPase activity, which is required for the activations of these proteins. Furthermore, the $\alpha$ subunit of Gs can be ADP-ribosylated by CTX, and the polypeptide currently designated Gi $\alpha$ s and the very similar Go $\alpha$ can be ADP-ribosylated by PTX. We previously showed by Western blotting that the $\mathrm{G}$ proteins $\mathrm{Gq}(42 \mathrm{kDa})$, Gi1 (40 kDa), Gi2 (40 kDa), Gi3 (40 kDa), Go (40 kDa), and Gs $(46 \mathrm{kDa})$ are expressed in esophageal smooth muscle cells (Yang et al., 2000). In the present study, pretreatment of PTX inhibited both 'on' and 'off' EFS-induced contractions. Also, CTX inhibited both EFS-induced contractions. These results imply that EFS-induced 'on' and 'off' contractions involve PTX-sensitive Gi proteins, the CTX-sensitive Gs protein.

Esophageal contraction in response to Ach is mediated by $\mathrm{M}_{2}$ muscarinic receptors, because Ach-induced contraction is selectively inhibited by the $\mathrm{M}_{2}$ muscarinic antagonist methoctramine. Furthermore, $\mathrm{M}_{2}$ muscarinic receptor is predominantly linked with $\mathrm{G}_{\mathrm{i} 3}$, because Ach-induced permeable cell contraction is inhibited by antibodies against the $\alpha$-subunit of $\mathrm{G}_{\mathrm{i} 3}$ (Sohn et al., 1993; Sohn et al., 1995). Moreover, G-proteins are linked to phospholipase, which generates intracellular second messengers from membrane phospholipids, and the Ach-induced contraction of esophageal circular muscle cells is inhibited by selective inhibitors or antibodies of phosphatidylcholine-specific phospholipase $\mathrm{C}$ (PC-PLC), PLD, and $\mathrm{CPLA}_{2}$, which suggests that $\mathrm{G}_{\mathrm{i} 3}$ and these phospholipases are linked (Sohn et al., 1993; Sohn et al., 1995). To identify the phospholipase that mediates the contraction of esophageal smooth muscle, we utilized the phospholipase inhibitors D609 (a phosphatidylcholine-phospholipase C inhibitor), U73122 (a phosphatidylinositol-phospholipase C inhibitor), pCMB (a phospholipase D inhibitor), and DEDA (a phospholipase $\mathrm{A}_{2}$ inhibitor). However, these inhibitors were found to have no effect on EFS-induced 'on' and 'off' contractions, which suggests that phospholipases do not participate in the muscle contraction induced by EFS.

These putative conclusions are based on the assumption that the activation of L-type $\mathrm{Ca}^{2+}$ channel is activated by G-protein directly, and not by a second messenger. However, it remains to be demonstrated whether G-protein interacts with L-type $\mathrm{Ca}^{2+}$ channel directly using cell-attachedrecording tests or whether the signaling pathway is activated by the $\alpha$ or $\beta \gamma$ subunits of G-protein.

We recently reported that rho-associated kinase may be involved in neural-evoked and acetylcholine-induced contraction via its translocation to the membrane in feline esophageal smooth muscle (Park et al., 2006; Park et al., 2009). Furthermore, it remains to be determined whether other kinases, such as, protein kinase C, PI-3 kinase, cAMP dependent kinase, and cGMP dependent kinase may have any effects.

NO relaxes LES and hyperpolarizes esophageal circular smooth muscle and the LES (Du et al., 1991; Murray et al., 1991; Conklin et al., 1993). Furthermore, it has also been shown that cGMP mediates the non-adrenergic non-cholinergic-induced hyperpolarization of esophageal smooth muscle (Conklin and $\mathrm{Du}, 1992$ ). In addition, $\mathrm{K}^{+}$ channel opening has been reported to mediate hyperpolarizations by $\mathrm{NO}$ and inhibitory junction potentials in opossum esophagus (Cayabyab and Daniel, 1995). Three outward $\mathrm{K}^{+}$currents are present in circular smooth muscle cells of the opossum esophagus, and NO modulates a calciumactivated potassium current in opossum esophageal muscle cells (Murray et al., 1995). Accordingly, we studied whether $\mathrm{K}^{+}$channel is involved in EFS-induced 'on' and 'off' contractions in cat esophageal smooth muscle. We found that pinacidil $\left(\mathrm{a} \mathrm{K}^{+}\right.$channel opener) decreased the amplitudes of both EFS-induced contractions, which suggests that $\mathrm{K}^{+}$
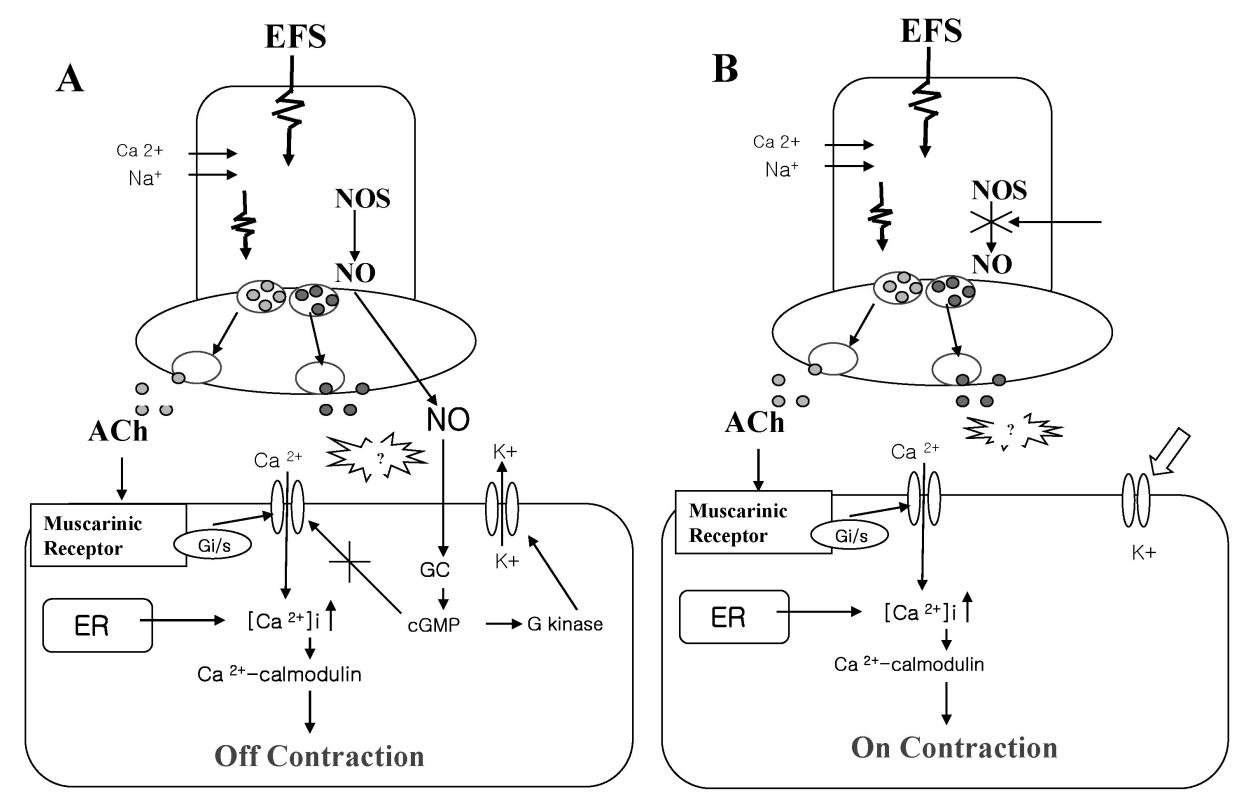

Fig. 8. The signaling diagram induced by EFS in cat esophageal muscle. The 'off' contraction (A) is probably mediated via NO-mediated $\mathrm{G}$ kinase dependent relaxation. Interestingly, our findings suggest that 'on' and 'off' (B) contractions are mediated by $\mathrm{Gi} / \mathrm{s}$ proteins via the opening of L-type $\mathrm{Ca}^{2+}$ channel, and that these contractions are augmented by the blocking of $\mathrm{Ca}^{2+}$-dependent $\mathrm{K}^{+}$channel. However, it remains to be determined which muscarinic receptor and whether contractile proteins and intracellular $\mathrm{Ca}^{2+}$ stores are involved in EFS-induced 'on' and 'off' contraction. 
efflux through $\mathrm{K}^{+}$channel affects the contraction elicited by EFS. Furthermore, both EFS-induced contractions were increased by TEA, a $\mathrm{K}^{+} \mathrm{Ca}^{-}$channel blocker, which indicates that $\mathrm{K}^{+}{ }_{\mathrm{Ca}}-$ channel affects the contraction of esophageal smooth muscle, which is consistent with the role played by $\mathrm{K}^{+}$channels in human esophageal muscle (Wade et al., 1999).

In summary, our findings (Fig. 8) suggest that Gs/i proteins mediate EFS-induced contraction. However, it has not been established whether L-type $\mathrm{Ca}^{2+}$ channel are activated by G-protein subunits directly or by second messengers indirectly. In addition, $\mathrm{K}^{+}$channel affects EFS-induced 'on' and 'off' contraction, and that $\mathrm{K}^{+} \mathrm{Ca}^{-}$channel may limit the depolarization of esophageal smooth muscle. Further studies are required to characterize the physiological regulation of $\mathrm{Ca}^{2+}$ channel and to investigate the involvements of muscarinic receptor, intracellular $\mathrm{Ca}^{2+}$ stores, and of other $\mathrm{K}^{+}$ channels in EFS-induced 'on' and 'off' contractions.

\section{REFERENCES}

Archer SL, Huang JM, Hampl V, Nelson DP, Shultz PJ, Weir EK. Nitric oxide and cGMP cause vasorelaxation by activation of a charybdotoxin-sensitive $\mathrm{K}$ channel by cGMP-dependent protein kinase. Proc Natl Acad Sci USA 91: 7583-7587, 1994

Behar J, Guenard V, Walsh JH, Biancani P. VIP and acetylcholine: neurotransmitters in esophageal circular smooth muscle. Am $J$ Physiol 257: G380-385, 1989.

Berridge MJ. Inositol trisphosphate and calcium signalling. Nature 361: 315-325, 1993.

Biancani P, Hillemeier C, Bitar KN, Makhlouf GM. Contraction mediated by $\mathrm{Ca}^{2+}$ influx in esophageal muscle and by $\mathrm{Ca}^{2+}$ release in the LES. Am $J$ Physiol 253: G760-766, 1987.

Biancani P, Walsh JH, Behar J. Vasoactive intestinal polypeptide. A neurotransmitter for lower esophageal sphincter relaxation. J Clin Invest 73: 963-967, 1984.

Bolotina VM, Najibi S, Palacino JJ, Pagano PJ, Cohen RA. Nitric oxide directly activates calcium-dependent potassium channels in vascular smooth muscle. Nature 368: 850-853, 1994.

Carabelli V, Hernandez-Guijo JM, Baldelli P, Carbone E. Direct autocrine inhibition and cAMP-dependent potentiation of single L-type $\mathrm{Ca}^{2+}$ channels in bovine chromaffin cells. $J$ Physiol 532: 73-90, 2001.

Casey PJ, Gilman AG. G protein involvement in receptor- effector coupling. J Biol Chem 263: 2577-2580, 1988.

Cayabyab FS, Daniel EE. $\mathrm{K}^{+}$channel opening mediates hyperpolarizations by nitric oxide donors and IJPs in opossum esophagus. Am J Physiol 268: G831-842, 1995.

Christinck F, Jury J, Cayabyab F, Daniel EE. Nitric oxide may be the final mediator of nonadrenergic, noncholinergic inhibitory junction potentials in the gut. Can J Physiol Pharmacol 69: 1448 $-1458,1991$.

Conklin JL, Du C. Guanylate cyclase inhibitors: effect on inhibitory junction potentials in esophageal smooth muscle. Am J Physiol 263: G87-90, 1992.

Conklin JL, Du C, Murray JA, Bates JN. Characterization and mediation of inhibitory junction potentials from opossum lower esophageal sphincter. Gastroenterology 104: 1439-1444, 1993.

Crist J, Gidda JS, Goyal RK. Characteristics of 'on' and 'off' contractions in esophageal circular muscle in vitro. Am J Physiol 246: G137-144, 1984.

Dalziel HH, Thornbury KD, Ward SM, Sanders KM. Involvement of nitric oxide synthetic pathway in inhibitory junction potentials in canine proximal colon. Am J Physiol 260: G789792, 1991.

Dascal N. Ion-channel regulation by G proteins. Trends Endocrinol Metab 12: $391-398,2001$.

Diamant NE. Physiology of esophageal motor function. Gastroenterol Clin North Am 18: 179-194, 1989.
Du C, Murray J, Bates JN, Conklin JL. Nitric oxide: mediator of NANC hyperpolarization of opossum esophageal smooth muscle. Am J Physiol 261: G1012-1016, 1991.

Fleischmann BK, Murray RK, Kotlikoff MI. Voltage window for sustained elevation of cytosolic calcium in smooth muscle cells. Proc Natl Acad Sci USA 91: 11914-11918, 1994.

Goyal RK, Rattan S, Said SI. VIP as a possible neurotransmitter of non-cholinergic non-adrenergic inhibitory neurones. Nature 288: $378-380,1980$.

Hillemeier C, Bitar KN, Marshall JM, Biancani P. Intracellular pathways for contraction in gastroesophageal smooth muscle cells. Am J Physiol 260: G770-775, 1991.

Ivanina T, Blumenstein Y, Shistik E, Barzilai R, Dascal N. Modulation of L-type $\mathrm{Ca}^{2+}$ channels by gbeta gamma and calmodulin via interactions with $\mathrm{N}$ and $\mathrm{C}$ termini of alpha 1C. $J$ Biol Chem 275: 39846-39854, 2000.

Jessell TM, Kandel ER. Synaptic transmission: a bidirectional and self-modifiable form of cell-cell communication. Cell 72 Suppl: $1-30,1993$.

Kelly RB. Storage and release of neurotransmitters. Cell 72 Suppl: $43-53,1993$.

Miyoshi H, Nakaya Y. Endotoxin-induced nonendothelial nitric oxide activates the $\mathrm{Ca}^{2+}$-activated $\mathrm{K}^{+}$channel in cultured vascular smooth muscle cells. J Mol Cell Cardiol 26: 1487-1495, 1994.

Murray J, Du C, Ledlow A, Bates JN, Conklin JL. Nitric oxide: mediator of nonadrenergic noncholinergic responses of opossum esophageal muscle. Am J Physiol 261: G401-406, 1991.

Murray JA, Shibata EF, Buresh TL, Picken H, O'Meara BW, Conklin JL. Nitric oxide modulates a calcium-activated potassium current in muscle cells from opossum esophagus. Am J Physiol 269: G606-612, 1995.

Park SY, Shin CY, Song HJ, Min YS, La Hyen O, Lee JW, Kim do Y, Je HD, Sohn UD. Electrically stimulated relaxation is not mediated by GABA in cat lower esophageal sphincter muscle. Arch Pharm Res 29: 400-404, 2006.

Park SY, Song HJ, Sohn UD. Participation of Rho-associated kinase in electrical stimulated and acetylcholine-induced contraction of feline esophageal smooth muscle. Eur J Pharmacol 607: 220$225,2009$.

Pope CE 2nd. The esophagus for the nonesophagologist. Am $J$ Med 103: $19 \mathrm{~S}-22 \mathrm{~S}, 1997$.

Rattan S, Chakder S. Role of nitric oxide as a mediator of internal anal sphincter relaxation. Am J Physiol 262: G107-112, 1992.

Roman C. Nervous control of esophageal peristalsis. J Physiol (Paris) 58: 79-108, 1966.

Roman C, Car A. Esophageal contractions produced by stimulation of the vagus or of the medulla oblongata. J Physiol (Paris) 59: 377-398, 1967.

Sato K, Sanders KM, Gerthoffer WT, Publicover NG. Sources of calcium utilized in cholinergic responses in canine colonic smooth muscle. Am J Physiol 267: C1666-1673, 1994.

Sims SM, Jiao Y, Preiksaitis HG. Regulation of intracellular calcium in human esophageal smooth muscles. Am J Physiol 273: C1679-1689, 1997.

Sohn UD, Chiu TT, Bitar KN, Hillemeier C, Behar J, Biancani P. Calcium requirements for acetylcholine-induced contraction of cat esophageal circular muscle cells. Am J Physiol 266: G330338,1994 .

Sohn UD, Han B, Tashjian AH Jr, Behar J, Biancani P. Agonistindependent, muscle-type-specific signal transduction pathways in cat esophageal and lower esophageal sphincter circular smooth muscle. J Pharmacol Exp Ther 273: 482-491, 1995.

Sohn UD, Harnett KM, De Petris G, Behar J, Biancani P. Distinct muscarinic receptors, $G$ proteins and phospholipases in esophageal and lower esophageal sphincter circular muscle. $J$ Pharmacol Exp Ther 267: 1205-1214, 1993.

Somlyo AP, Somlyo AV. Signal transduction and regulation in smooth muscle. Nature 372: 231-236, 1994.

Tottrup A, Svane D, Forman A. Nitric oxide mediating NANC inhibition in opossum lower esophageal sphincter. Am J Physiol 260: G385-389, 1991. 
Unwin N. Neurotransmitter action: opening of ligand-gated ion channels. Cell 72 Suppl: $31-41,1993$.

van Breemen C, Saida K. Cellular mechanisms regulating $\left[\mathrm{Ca}^{2+}\right]_{\mathrm{i}}$ smooth muscle. Annu Rev Physiol 51: 315-329, 1989.

Viard P, Exner T, Maier U, Mironneau J, Nurnberg B, Macrez N. Gbetagamma dimers stimulate vascular L-type $\mathrm{Ca}^{2+}$ channels via phosphoinositide 3-kinase. Faseb $J$ 13: 685-694, 1999.

Wade GR, Laurier LG, Preiksaitis HG, Sims SM. Delayed rectifier and $\mathrm{Ca}^{2+}$-dependent $\mathrm{K}^{+}$currents in human esophagus: roles in regulating muscle contraction. Am J Physiol 277: G885-895, 1999.
Weisbrodt NW, Christensen J. Gradients of contractions in the opossum esophagus. Gastroenterology 62: 1159-1166, 1972.

Yamato S, Saha JK, Goyal RK. Role of nitric oxide in lower esophageal sphincter relaxation to swallowing. Life Sci 50: 1263 $-1272,1992$

Yang SJ, An JY, Shim JO, Park CH, Huh IH, Sohn UD. The mechanism of contraction by 2-chloroadenosine in cat detrusor muscle cells. J Urol 163: 652-658, 2000.

Zhong J, Dessauer CW, Keef KD, Hume JR. Regulation of L-type $\mathrm{Ca}^{2+}$ channels in rabbit portal vein by $\mathrm{G}$ protein alphas and betagamma subunits. J Physiol 517: 109-120, 1999. 